\title{
AN IDEAL HALALAN TOYYIBAN FOOD QUALITY MANAGEMENT (HTFQM) PRINCIPLES
}

\author{
NORAZILAWATI MD DAHLAL \\ International Institute for Halal Research and Training (INHART), International Islamic \\ University Malaysia, Jalan Gombak, 53100 Kuala Lumpur, Malaysia.
}

Corresponding author: noradahlal@iium.edu.my

(Received: $2^{\text {nd }}$ Jul. 2021, Accepted: 10 ${ }^{\text {th }}$ Jul. 2021, Published on-line: 26 ${ }^{\text {th }}$ Jul. 2021)

\begin{abstract}
Technically, the Halalan Toyyiban food quality system has used both conventional and halal standards to control quality. This serves as a greater impact on both technical and Syari'ah elements to enhance the marketability of Halalan Toyyiban food items locally and globally. According to some reports, certain producers could make an immediate profit by committing a food quality control infraction, such as food adulteration. As a result, the purpose of this study is to explore the ideal HTFQM principle that may be used in everyday activities rather than just for product quality. A qualitative inquiry was used to highlight the Halalan Toyyiban component in the Qur'an. The seven ideal principles of HTFQM could be established based on content analysis, considering all aspects of the physical and spiritual as well as material and intangible factors.
\end{abstract}

KEYWORDS: Halalan Toyyiban; Food quality management; Principles; Qur'anic; halal food

\section{INTRODUCTION}

Food quality management based on the Halalan Toyyiban concept is a strategy for ensuring the quality and safety of food products while also considering the Syari'ah requirements for Muslim consumers. However, by including halal and conventional food quality standards, Halalan Toyyiban food quality management (from now on would be referred to as HTFQM throughout this text) will be focused on consumerism and economics, (Norazilawati, 2017).

From a consumer viewpoint, HTQFM's mission is to protect customers from microbiological, chemical and physical risks present in food products, (Sikora, 2005). Thus, consumers have the option of purchasing Halalan Toyyiban food products due to their clean, safe and universally recognised quality attributes, (Hafsah et al., 2016; Mohd Al'Ikhsan \& Siti Salwa, 2015). The products are chosen based on their halal certification or halal logo, which indicates that they adhere to Halalan Toyyiban standards, (Sazelin \& Safiah, 2015). As a result, Malaysian halal certification has gained international recognition as a mark of halal quality assurance, (Mohd Al'Ikhsan \& Siti Salwa, 2016; Siti Hasnah, 2009). This creates new business prospects for 
industries and satisfies Muslim consumers worldwide. This advantage catalyses enterprises to premium on HTFQM in all Halalan Toyyiban food items to maximise marketability in the current economic climate.

Fundamentally, two critical factors influence the quality of food products; the purity aspect is required by Syari'ah law and secondly, safety and hygiene, which involves technological aspects. These two factors have contributed considerably to developing a complete application of the toyyiban concept, (Harlida \& Alias, 2014). Thus, the Halalan Toyyiban notion is not only fashionable, but it also satisfies the Syari'ah requirements for having a 'safe' connotation, as mandated by Allah SWT:

"O mankind eat from whatever is on earth (that is) lawful and good and do not follow the footsteps of Satan. Indeed, he is to you a clear." (al-Baqarat: 168)

However, when conventional food quality standards such as Good Manufacturing Practice (GMP) is used, the application of HTFQM becomes less holistic and incomplete, (Hayati@Habibah \& Khairul Anuar, 2009). As a result, the existing HTFQM approach will not be used as a foundation for daily human activities, let alone product quality. This is because GMP is claimed to be focused exclusively on product quality, which is defined as the physical and technological factors. As a conventional food quality standard, GMP has emphasised the western perspective, emphasising only factors of safety and hygiene based on the cutting-edge technology, excluding religious considerations deemed critical for Muslim consumers, (Ricca Rahman et al., 2011). As such, this paper will examine the ideal principle of HTFQM using Qur'anic scriptures that are associated with the concept of Halalan Toyyiban.

\section{MATERIALS AND METHODS}

This qualitative study analysed two sources using the content analysis method. To begin with, primary sources such as the Qur'an and hadith were referred to. Secondly, was by document evaluation on the secondary data, namely HTFQM-related documents.

This study relied heavily on primary Islamic sources of data as its primary source of information. The Qur'anic verses relating to the notion of Halalan Toyyiban were considered as data. The study consulted tafsir references in order to understand the Qur'an verses acquired. Tafsir al-Azhar (Hamka, 1982), Tafsir Ibn Kathir (Ibn Kathir, 2008) and Tafsir al-Maraghiy were chosen (Ahmad Mustafa Al-Maraghiy, 2001). At the same time, the use of hadith in this study served as an explanation for the Qur'anic verses that are mujmal or straightforward. Hadith was employed to bolster and explain the Qur'anic passages about the concept of Halalan Toyyiban.

Meanwhile, secondary data were gathered through the document review approach from written materials, either published or unpublished, employed in contemporary HTFQM processes. The Malaysian Halal Certification Procedure Manual (MPPHM), the halal standards MS1500: 2009 and MS1900: 2014 and the Food Act 1985 and Food Regulations 2009 are among them. Additionally, journal papers, books and theses on PKMHT; a Malay abbreviation of HTFQM were employed as secondary data in this study. ATLAS.ti was also used to analyse the data. 


\section{RESULTS AND DISCUSSION}

The study was done through an analysis of Qur'anic verses about the idea of Halalan Toyyiban. As illustrated in Figure 1, a total of 38 Qur'anic verses relating to the Halalan Toyyiban idea have been identified and successfully gathered. These verses define Halalan Toyyiban as a concept that encompasses components of worship (ibadah), Islamic commercial transaction law (muamalat), Islamic family law (munakahat) and Islamic criminal law (jinayat).

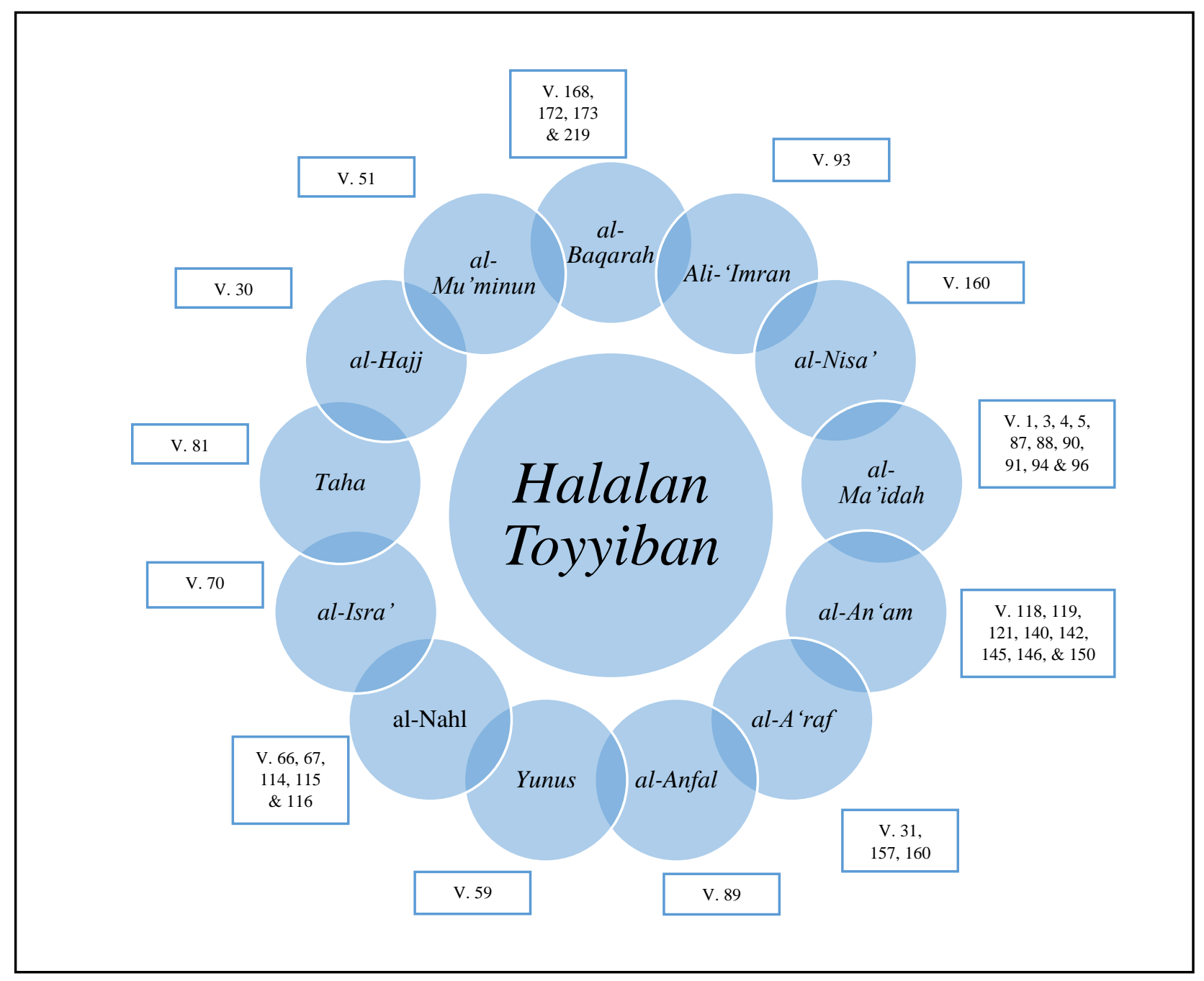

Figure 1: Selected passages from the Qur'an related to the notion of Halalan Toyyiban.

However, upon examining the written materials about the current HTFQM practice, at least 24 Qur'anic verses are cited as references when practising HTFQM. The results of 24 out of the 38 Qur'anic verses about the idea of Halalan Toyyiban were employed exclusively to execute HTFQM. The investigation discovered a pattern of repetition in which the same verses were used again; among mentioned are the verses from surah Ali- Imran (3:93), al-Nisa' (4:160), al-An 'am (6:150) and al-Nahl (16:116). Figure 2 shows a repetition of the verses discussed in the present HTFQM implementation discussion. 
The variation in the frequency of the verses indicated a varied emphasis on the current application of HTFQM. This will aid in understanding principles underlying the existing execution of HTFQM and then, followed by constructing the ideal concept of HTFQM by a careful examination of the selected verses.

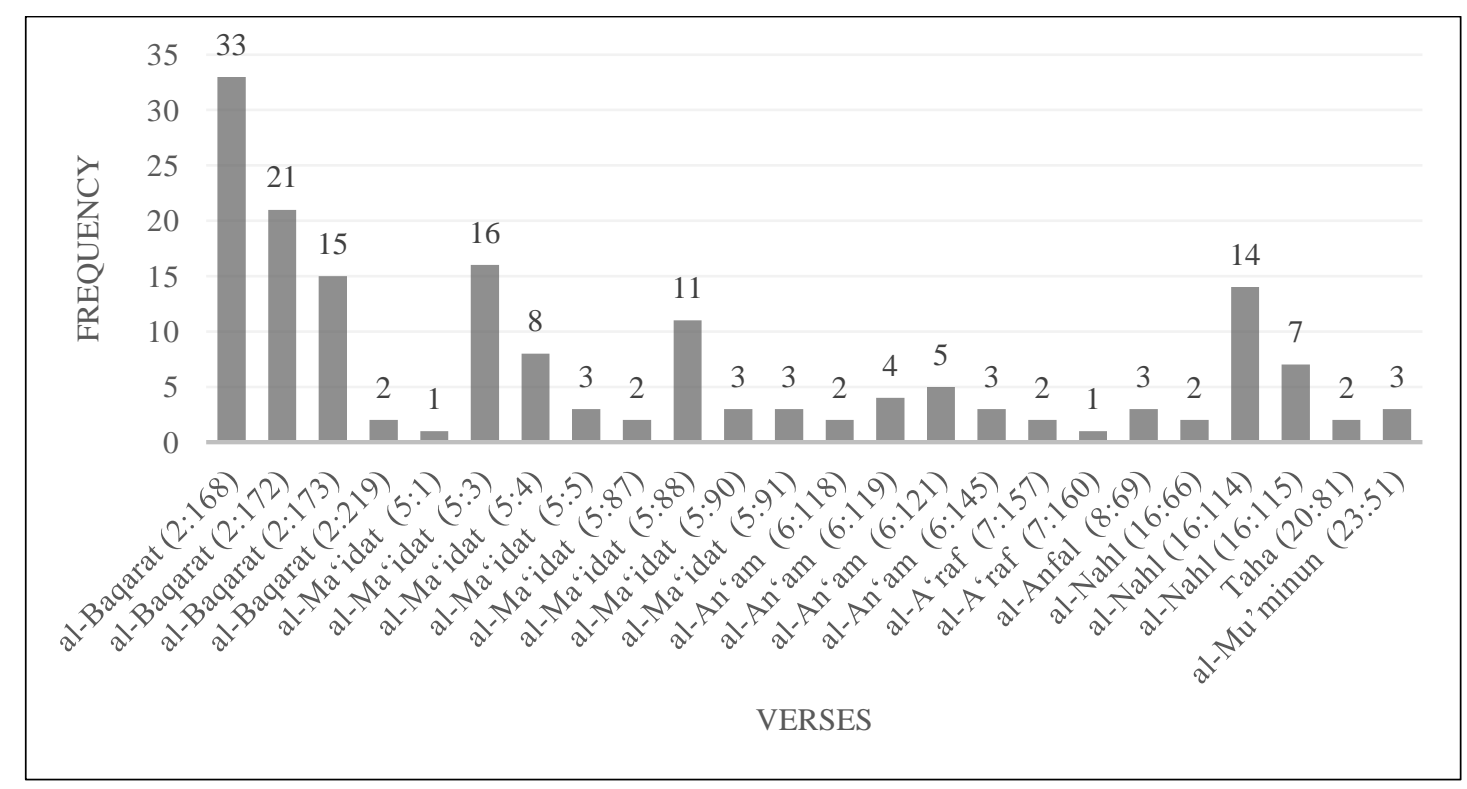

Figure 2: The reiteration of the verses that were used in discussing the current implementation of HTFQM.

The content analysis approach was used to analyse and categorised chosen Qur'anic passages. The study identified at least seven themes based on the classifications, which were subsequently defined as an ideal concept of HTFQM. They were (1) the features of food according to Islamic law; (2) the good source of food; (3) the quality, safety and hygiene of food; (4) obedient to the seven themes which were then formulated as an ideal principle of HTFQM commands and prohibitions of Allah SWT; (5) not excessive or extravagant; (6) the implications of good moral and spiritual; and (7) the goal of prosperity in the world and hereafter.

\subsection{Principle 1: The Features of Food According to Islamic Law}

According to al-Baqarat (2:173 \& 219); al-Ma'idat (5:3, 88 \& 91); and al-Nahl (16:115), the Qur'an clearly stated that banned foods include blood, pigs, carcasses and animals murdered in the name of Allah SWT. Additionally, intoxicating liquids such as alcoholic beverages are prohibited. Halal or haram food or drink is judged based on two criteria: its composition and source of revenue.

As stated in the hadith, a man presented Prophet Muhammad (PBUH) with a bag of intoxicants. As a result, he asked him, "Did you not realise that Allah SWT forbade it?." The guy then responded, "No, O Prophet!". The man then muttered to another person close, and Prophet Muhammad (PBUH) said, "What did you whisper to him?". "I instructed him to sell the intoxicants", the man replied. Abu Sa'id continued, "Then the man opened the bag of intoxicants and emptied it", (Sahih Muslim, Hadith 1548). 
According to al-An 'am (6:145), the forbidden foods are also contained in the interpretation of Qur'anic texts, including predatory creatures with fangs such as cats, dogs, bears and lions. This type of cuisine is prohibited due to its filthy and repulsive nature. Prophet Muhammad (PBUH) forbade the consumption of (the meat of) any taloned bird or predatory animal with canine teeth, (Sahih Muslim, Hadith 4752).

Other passages, such as al-Baqarat (2:172 \& 173), al-Ma'idat (5:4 \& 5) and al-An 'am (6:118), have emphasised the component of slaughter that is related to the sort of animal murdered and the method of slaughter. According to the tafsir, halal slaughter refers to the type of animal that is halal to be consumed. Simultaneously, the procedure requires that the animal be murdered in the name of Allah SWT with a sharp knife, enabling the blood to flow freely. Additionally, it has been declared in the Qur'an that game animals are halal when they are slaughtered according to a set of standards. This alludes to the hadith, which states, "Verily, Allah has prescribed kindness on everything; thus, when you slay, kill well and when you slaughter, slaughter well." Thus, each of you should sharpen his knife and allow the butchered animal to die in peace. (Hadith 4810) in Sahih Muslim. To summarise, the consideration of chosen verses and hadith demonstrates that Islamic law-compliant food characteristics have become the primary premise of HTFQM as shown in table 1 .

Table 1: Identification of the First Ideal Principles of HTFQM.

\begin{tabular}{ccl}
\hline P1 & Code no. & \multicolumn{1}{c}{ Description } \\
\cline { 2 - 3 } & $2: 173,219$ & The features of halal food that are mentioned are \\
$5: 3,88,91$ & blood, pork, carrion and khamr \\
& $6: 115$ & \\
\hline 2 & $6: 145$ & $\begin{array}{l}\text { Other types of haram food such as predatory } \\
\text { animals and birds of preys }\end{array}$ \\
& $2: 172 \& 173$ & Permitted animals with halal slaughtering method \\
$5: 4 \& 5$ & \\
$6: 118$ & $16: 66$ & $\begin{array}{l}\text { Permitted foods include livestock animals; except } \\
\text { the types specified in codes } 1,2 \text { and } 3\end{array}$ \\
\hline
\end{tabular}

\subsection{Principle 2: The Good Source of Food}

While the food collected or manufactured satisfies the first premise, the production method may sometimes involve unlawful sources and render the food non-halal. Illegal sources relate to food obtained through deception, theft or any other act that causes harm to others. Surah al-Ma'idat explains this $(5: 88)$, for instance, fabricating phoney food by forging food ingredients. While the dish is excellent, the ingredients are gained through deception, such as a stolen goat. Even if the goat is slain and prepared correctly according to the Syari'ah manner, it is still prohibited.

Meanwhile, al-Baqarat (2:219) and al-Ma'idat (5:90) state that lottery and gambling results are also illicit and prohibited sources of information. These types of unethical and illegal sources are not permitted as financial sources for implementing HTFQM. Additionally, the sale of haram food is prohibited (as stated in the first principle). This refers to one hadith, which stated, "Verily, Allah and His Messenger have prohibited the selling of intoxicants, carcasses, pigs and idols". Then he was asked by his followers, "Yes, Messenger of Allah! What is the rule regarding the fat contained 
within the carcass? Because the fat from the corpse is used to lubricate the skin and light lamps". As a result, He stated, "No! It is prohibited". Then he explained, "as a result of the fat, Allah SWT cursed the Jews. Allah forbids people from processing fat from carcasses, but they still do so. Then they sell and pocket the proceeds". (Sahih Muslim, Hadith 1550; Sahih al-Bukhari, Hadith 1096).

Alternatively, the sources of halal ingredients are examined in an Akad (sell and buy agreement), as specified in surah al-Ma'idat (5:1). Although the content source is halal, it cannot be used if it is not ideal in an Akad (agreement). This pact is for the good of humanity. Unless the flawed agreement legalises the illegal or otherwise, the agreement entails keeping a promise. According to Prophet Muhammad (PBUH), this signifies, "Peace can exist between fellow Muslims, except for peace that prohibits halal acts or permits haram acts. Muslims always adhere to the requirements, except those prohibiting halal practices or permitting haram practises". (Sunan al-Tirmizi, Hadith 1370). To summarise, the discussion of principle 2 focuses on the permissible sources of money for implementing HTFQM, as illustrated in table 2 below.

Table 2: Identification of the Second Ideal Principles of HTFQM.

\begin{tabular}{|c|c|c|c|}
\hline \multirow[t]{4}{*}{$\mathbf{P 2}$} & Code no. & Verses & Description \\
\hline & 5 & $5: 88$ & $\begin{array}{l}\text { Unethical sources are not permitted even though } \\
\text { the type of food is halal, as stated in P1 }\end{array}$ \\
\hline & 6 & $\begin{array}{c}2: 219 \\
5: 90\end{array}$ & $\begin{array}{l}\text { Financial sources such as lottery and gambling are } \\
\text { not permitted }\end{array}$ \\
\hline & 7 & $5: 1$ & $\begin{array}{l}\text { The sources come from the imperfect agreement } \\
(A k a d) \text { are not permitted }\end{array}$ \\
\hline
\end{tabular}

\subsection{Principle 3: The Quality, Safety, and Hygiene of Food}

Principle 3 is based on surah al-An 'am (6:145) and al-Nahl (16:114), which explain the nature of food when weighed in terms of toyyiban (good) and khaba'ith (evil) (vile). Food that is repulsive and despised should be avoided. This is a reference to Prophet Muhammad (PBUH) hadith regarding the Khaibar war. The Prophet's companions were required to consume garlic. We ate a lot since we were starving. Then we went to the mosque, where Prophet Muhammad (PBUH) smelled the garlic and ordered, "whoever consumes the stinky fruit, stay away from us in the mosque". "Haram, haram!" chanted the audience. When he heard this, Prophet Muhammad (PBUH) said, "O people! Indeed, I forbid nothing that Allah has decreed permissible, save that the plants stink", (Sahih Muslim, Hadith 1965).

Another issue is the food's safety mentioned in surah al-Ma'idat (5:3 \& 87) and al-Araf (7:157). While halal and correctly prepared food (halal and cooked sources) is permitted in Islam, it is also banned if it is expired and stale or involves imprecise cooking procedures that might harm the health. Additionally, surah al-Ma'idat (5:4) explains the quality of food associated with Allah SWT creation of animals or plants that is halal and fit for human eating. The nice things that Allah SWT has made legal are delectable and nutritious foods that contain nutrients necessary for good health. According to Prophet Muhammad (PBUH), when he noticed a sheep donated to Maimunah had died, he asked, "Why don't you take advantage of the skin?". They replied, "because the sheep is unwell". "Indeed, it is forbidden to eat it", Prophet Muhammad (PBUH) stated. (Sahih Bukhari, Hadith 0773). In short, when adopting HTFQM, the aspects of quality, safety and hygiene should be considered and this forms the third ideal concept of HTFQM as mentioned in table 3. 
Table 3: Identification of the Third Ideal Principles of HTFQM.

\begin{tabular}{|c|c|c|c|}
\hline \multirow[t]{5}{*}{$\mathbf{P 3}$} & Code no. & Verses & Description \\
\hline & 8 & $\begin{array}{c}6: 145 \\
16: 114\end{array}$ & $\begin{array}{l}\text { Halal food is measured from the aspect of good } \\
\text { (toyyiban) vs vile (khaba'ith) }\end{array}$ \\
\hline & 9 & $\begin{array}{l}5: 3,87 \\
7: 157\end{array}$ & Improper cooking process \\
\hline & 10 & $5: 4$ & $\begin{array}{l}\text { Halal food is delicious and beneficial food that } \\
\text { contains nutrients for good health }\end{array}$ \\
\hline & 11 & $\begin{array}{c}2: 173 \\
5: 4,88 \\
16: 114\end{array}$ & $\begin{array}{l}\text { Haram foods (stated in P1) are naturally unclean } \\
\text { and harmful to human consumption }\end{array}$ \\
\hline
\end{tabular}

\subsection{Principle 4: Obedient to the Commands and Prohibitions of Allah SWT}

Surah al-Ma'idat (5:1 \& 87); al-Araf (7:160); and al-An'am (6:121 \& 145) all discussed the importance of obeying Allah SWT's mandates and prohibitions. This component has evolved into the fourth principle of HTFQM implementation. This refers to establishing the halal and haram laws of food following His will, using His wisdom and advantages. As a result, Allah SWT banned the act of prohibiting what Allah SWT permits and the use of Allah's bounties for the sake of disobedience.

The source of halal and haram law is absolute, as stated in surah al-Baqarat (2:219); alMa'idat (5:1 \& 87); al-A 'raf (7:160); and al-Mu'minun (23:51) as shown in table 4. As a believer in Allah SWT, a man is obligated to obey Allah SWT's orders and prohibitions without reservation, because a vow binds the man to Allah $S W T$ as a servant. Choosing halal and excellent meals is a matter of faith and piety. This is a hadith from the Prophet Muhammad (PBUH); when Nu'man bin Qawqal came to asking him a question, he said, "yes, Prophet! When I say the obligatory prayers, do you believe that if I avoid what is haram and practise what is halal, I would be admitted to heaven?". "Yes, it is true!", responded by Prophet Muhammad (PBUH), (Sahih Muslim, Hadith 0008).

Table 4: Identification of the Fourth Ideal Principles of HTFQM.

\begin{tabular}{ccl} 
P4 Code no. & Verses & \multicolumn{1}{c}{ Description } \\
\hline 12 & $5: 1$ & Determination of the halal and haram laws of \\
$7: 160$ & food according to Allah $S W T$ \\
& $6: 121,145$ & \\
\hline $2: 219$ & A man is obliged to follow the commands and \\
$5: 1,87$ & prohibitions of Allah $S W T$ without objection \\
$7: 160$ & \\
$23: 51$ & \\
\hline
\end{tabular}

\subsection{Principle 5: Not Excessive or Extravagant}

Principle 5 is drawn from surah al-Baqarat (2:172 \& 173); al-Ma'idat (5:4 \& 88); al-An'am (6:119 \& 145); al-Nahl (16:115); and Taha (20:81), which discussed regarding rukhsah. Rukhsah, or concession, refers to judgements that are sanctioned as a result of impediments and hardships. 
This concept of rukhsah is founded on the axiom that 'difficulty justifies comfort'. Even though the law is permissive in terms of halal and haram food, human beings must exercise greater caution to avoid overdoing it, which has become a critical part of implementing HTFQM. As a result, this concession is made at an acceptable rate to avert emergencies and save lives.

According to surah al-Baqarat (2:173); al-Nahl (16:114); Taha (20:81); and al-Mu'minun (23:51), Allah SWT also prohibits excess or extravagance that causes individuals to focus exclusively on feeding their stomachs without regard for the halal or haram status of the food as shown in table 5. This can lead to people losing faith in Allah SWT. This clearly demonstrates that a real believer in Allah SWT consumes only halal food as an expression of submission to Allah SWT.

Table 5: Identification of the Fifth Ideal Principles of HTFQM.

\begin{tabular}{|c|c|c|c|}
\hline \multirow[t]{3}{*}{ P5 } & Code no. & Verses & Description \\
\hline & 14 & $\begin{array}{c}2: 172,173 \\
5: 4,88 \\
6: 119,145 \\
16: 115 \\
20: 81\end{array}$ & $\begin{array}{l}\text { Rukhsah or concession means rulings sanctioned } \\
\text { due to hindrances and hardships, but people } \\
\text { should be more careful not to overdo it or } \\
\text { excessive }\end{array}$ \\
\hline & 15 & $\begin{array}{c}2: 173 \\
16: 114 \\
23: 51\end{array}$ & $\begin{array}{l}\text { The excessiveness and extravagance are not } \\
\text { permitted }\end{array}$ \\
\hline
\end{tabular}

\subsection{Principle 6: The Implications of Good Moral and Spiritual}

The implications of moral and spiritual well-being as explained in surah al-Baqarat (2:172); al-Ma'idat (5:4), and al-Mu'minun (23:51) have evolved into the sixth principle of HTFQM. Table 6 as shown below would summarize these details mentioned. Consumption of halal food has a profound impact on the physical, mental and spiritual development of humans. According to Prophet Muhammad (PBUH), "the halal is clear, the haram is clear, and in between they are ambiguous topics that are unknown to most people". Whoever is suspicious of these obscure facts has acquitted himself of his religion and honour. Additionally, anyone who engages in them engages in haram. (Sahih Muslim, Hadith 1568).

The mandate of Allah SWT in surah Taha (20:81) and al-Mu'minun (23:51) on the food to the stomach (which should be from good and halal sources) will not only affect the blood flow to the body and subsequently affecting the way one thinks but also affecting the spirituality and lust. Allah SWT bestows bounties based on halal so that human beings can choose between halal and good food and sources of sustenance. The influence of Halalan Toyyiban food on human spirituality, which is a pure heart, so that Allah SWT will accept his prayers and worship. This relates to a hadith by Prophet Muhammad (PBUH) concerning a guy who walked for an extended period due to the distance he had travelled until his hair became knotted and caked with dust. "O my Lord! O my Lord!", the guy prayed as he raised his hands towards heaven. Prophet Muhammad (PBUH) stated that his food comes from haram sources, his drink comes from haram sources, his clothing also be from haram sources and he is raised with haram food; how can Allah accept his prayer?, (Sahih Muslim, Hadith 0971). 
Table 6: Identification of the Sixth Ideal Principles of HTFQM.

\begin{tabular}{|c|c|c|c|}
\hline \multirow[t]{4}{*}{ P6 } & Code no. & Verses & Description \\
\hline & 16 & $\begin{array}{l}2: 172 \\
5: 4 \\
23: 51\end{array}$ & $\begin{array}{l}\text { Halal food has a significant impact on the } \\
\text { physical, mental and soul formation of human } \\
\text { beings }\end{array}$ \\
\hline & 17 & $\begin{array}{l}20: 81 \\
23: 51\end{array}$ & $\begin{array}{l}\text { The halal and good food that enters the human } \\
\text { body will affect the blood flow, the way the brain } \\
\text { thinks, and spirits }\end{array}$ \\
\hline & 18 & $\begin{array}{l}2: 172,173 \\
5: 88\end{array}$ & $\begin{array}{l}\text { Allah } S W T \text { will grant prayers from a pure heart as } \\
\text { an effect of halal food consumption }\end{array}$ \\
\hline
\end{tabular}

\subsection{Principle 7: The Goal of Prosperity in The World and Hereafter}

The final premise of HTFQM is the pursuit of the world and eternal prosperity. This relates to numerous Qur'anic verses that had been discussed of the Halalan Toyyiban notion, including $\mathrm{Al}$ Ma'idat (5:5), al-An'am (6:119), and al-Nahl (16:114). Table 7 as shown below would summarize these details mentioned. Each facet of Halalan Toyyiban has been covered in greater detail in the preceding HTFQM principles. The purpose of these ideas is to achieve worldly and eternal wealth. For instance, choosing a food product that adheres to Principle 1 - the characteristics of food according to Islamic law - Principle 2 - good sources of food - and Principle 3 - food quality, safety and hygiene - can help the world's well-being. However, if individuals choose to consume haram food or violate these guidelines, even if they are careful in their devotion, their worship would be rejected by Allah SWT. Indeed, food selection and quality management based on the principles mentioned above will substantially impact us in this world and the hereafter.

Table 7: Identification of the Seventh Ideal Principles of HTFQM.

\begin{tabular}{|c|c|c|c|}
\hline \multirow[t]{3}{*}{ P7 } & Code no. & Verses & Description \\
\hline & 19 & $5: 5$ & $\begin{array}{l}\text { Haram food gains are harmful both in this life and } \\
\text { hereafter }\end{array}$ \\
\hline & 20 & $\begin{array}{c}6: 119 \\
16: 114\end{array}$ & $\begin{array}{l}\text { Khamr is forbidden due to the harmful effect on } \\
\text { health and spiritual that will affect their treatment } \\
\text { in the hereafter }\end{array}$ \\
\hline
\end{tabular}

\section{CONCLUSION}

The current application of HTFQM, which encompasses both conventional and halal standards, is not holistic or exhaustive. As a result, this study was done in order to identify an ideal principle of HTFQM based on Qur'anic verses relating to Halalan Toyyiban and supporting hadith. There have been 38 Qur'anic passages discovered that refers to the idea of Halalan Toyyiban. This study addressed seven ideal guidelines for regulating the quality of Halalan Toyyiban cuisine. The seven principles are as follows: (1) the characteristics of food according to Islamic law; (2) the source of food; (3) the quality, safety, and hygiene of food; (4) compliance with Allah SWT commands and prohibitions; (5) not excessive or extravagant; (6) the implications of moral and spiritual well-being; and (7) the goal of worldly and eternal prosperity. 


\section{REFERENCES}

[1] Ahmad Mustafa Al-Maraghiy. (2001). Tafsir al-Maraghiy Jilid 1-9 (Terj. Muhammad Talib: Tafsir al-Maraghiy). Kuala Lumpur: Dewan Bahasa \& Pustaka.

[2] Hafsah Yahya, Zainal Samicho, \& Aida Firdaus Muhammad Nurul Azmi. (2016). A review on application of halalan-toyyiban risk management plan (HTRMP) and frozen food chain during warehousing activities for maintaining halal, safety, and quality. Journal of Applied Environmental and Biological Sciences, 6(11), 96-12.

[3] Hamka, AbdulMalik AbdulKarim Amrullah. (1982). Tafsir Al-Azhar (Jilid 1 - 8). Jakarta: Pustaka Panjimas.

[4] Harlida Abdul Wahab, \& Alias Azhar. (2014). Halalan tayyiban dalam kerangka perundangan Malaysia. Kanun, 26, 103-120.

[5] Hayati @ Habibah Abdul Talib, \& Khairul Anuar Mohd Ali. (2009). An overview of Malaysian food industry: The opportunity and quality aspects. Pakistan Journal of Nutrition, 8(5), 507-517. Doi: 10.3923/pjn.2009.507.517

[6] Ibn Kathir. (2008). Tafsir al-Qur'an al-'Azim: Tafsir Ibn Kathir (Jilid 1-6).'Abd al-Rezzaq Mahdi (Ed.). Beirut: Dau al-Kitab al-'Arabi.

[7] Mohd Al’Ikhsan Ghazal \& Siti Salwa Md. Sawari. (2015). Standard piawaian halal di Malaysia menurut perundangan, kelebihan dan kekurangan. UMRAN International Journal of Islamic and Civilizational Studies, 02, 56-61. www.http://jurnalumran.utm.my/index.php/umran

[8] Mohd Al'Ikhsan Gazali \& Siti Salwa Md. Sawari. (2016). Malaysian Halal Certification: A Review of Global Standard Potential. Paper presented at the Graduate Student Conference 2016, National Institute of Education, Singapore. Doi: 10.13140/RG.2.2.34912.69129

[9] Norazilawati Md Dahlal. (2017). Konsep Pengurusan Kualiti Makanan Halalan Tayyiban. PhD Thesis. Unpublished: Universiti Sains Malaysia.

[10] Ricca Rahman Nasaruddin, Maizirwan Mel, Faizah Fuad, Irwandi Jaswir, \& Hamidon Abd. Hamid. (2011). The importance of standardised Islamic Manufacturing (IMP) for food and pharmaceutical productions. Kertas kerja dibentangkan di 2nd International Conference on Professional Ethics and Education in Engineering 2011 (ICEPEE'11), Kuala Lumpur.

[11] Sazelin Arif, \& Safiah Sidek. (2015). Application of Halalan Tayyiban in the Standard Reference for Determining Malaysian Halal Food. Asian Social Science, 11(17). Doi:10.5539/ass.v11n17p116

[12] Sikora, T. (2005). Methods and systems of food quality and safety assurance. Polish Journal of Food and Nutrition Sciences, 14/55(SI 1), 41-48. 